\title{
INTERCULTURAL ASPECTS IN TEACHING INDONESIAN AS A FOREIGN LANGUAGE (BIPA)
}

\author{
Winasti Rahma Diani, Sisilia Setiawati Halimi \\ Universitas Indonesia, Depok, Indonesia \\ E-mail: winastirahma@gmail.com
}

Received: 22 October 2020

Accepted: 10 December 2020

\begin{abstract}
Learners should be intercultural speakers in foreign language teaching that promotes the intercultural dimension. In mastering the intercultural competencies, students are expected to be able to position themselves based on the background of their origin cultures and the culture that they learn in intercultural situations. This study aimed to find out how teaching the intercultural competencies was implemented in the course of Indonesian as a Foreign Language (BIPA), especially at the beginner level. This study investigated the intercultural teaching through textbooks, classroom observation, cultural program, and assessment used for the beginner course at the Institution $X$. The results of the analysis showed that the textbooks used contain themes of intercultural learning for the survival needs of novice students. The results of the classroom observation also showed that intercultural teaching was well executed. However, the results of the field trip observations that were part of the cultural program showed that the activities were not integrated with language learning. Besides, the results of the assessment analysis indicated that the exercise books and the tests used were not considered as the intercultural aspects. Therefore, this study is expected to provide input for intercultural teaching in BIPA courses, especially at the beginner level.
\end{abstract}

Keywords: assessment, intercultural learning, class observation, cultural program.

\section{Introduction}

In the study of foreign language teaching, practitioners and academicians have recognized the importance of communicative language teaching (CLT). Based on this approach, the learners require not only grammatical skills and knowledge but also the ability to properly apply the foreign language that has been learned. This is important because it aims to enable learners to appropriately communicate culturally. According to Standards (Moeller \& Nugent, 2014), a culturally appropriate interaction occurs when two individuals participate in a reciprocal conversation based on a common understanding and openness.

From communicative language teaching, the study of foreign language teaching continues to grow. The Council of Europe that developed the Common European Framework of Reference (CEFR) has made improvement by incorporating the intercultural dimension in CEFR. The purpose is to take into account that the intercultural dimension can make the learner as an intercultural speaker or mediator between his or her original cultural background and the culture that have been studied. 
The aforementioned intercultural competence has drawn the attention of the researchers to conduct this study. Based on the literature and findings from the internet, the researchers have not found any studies on the intercultural competence in teaching Indonesian as a Foreign Language (BIPA). Thus, this study is one of its kinds in the Indonesian context.

Intercultural competence is vital for the learners to be able to communicate well in intercultural situations, i. e. situations where people from different cultural backgrounds gather in a specific place. Without intercultural competence, learners can only understand the language used by an interlocutor. As a result, learners can miss the message the interlocutor wants to convey because it lacks the intercultural competence to understand the culture or background of the interlocutor.

Furthermore, culture is considered as an important matter in Indonesian society. For example, in Indonesian culture, asking the age of a person early in the introduction is a common thing. This is done to determine a polite greeting sentence so that further communication can run well. However, for foreigners who do not understand the purpose, this can be considered rude. Therefore, the people involved in intercultural situations are expected to understand each other's cultural background.

The researchers chose Institution $X$ as the research place because an institution that provides Indonesian as a Foreign Language (BIPA) courses supporting the learning of Indonesian culture. Another supporting aspect is the location of Institution $\mathrm{X}$ in Daerah Istimewa Yogyakarta known for the richness of its local culture. The researchers are interested in studying the intercultural competence integrated in textbooks, additional programs, and assessment contained in the BIPA course for beginner level.

\section{Literature Review}

\subsection{Intercultural Dimension}

The intercultural dimension provides a new different orientation in foreign language teaching. According to Scarino (2010), prior to the implementation of intercultural dimension, the cultural component of foreign language teaching includes only the generalization of knowledge about the target culture and its people, from literature and art to everyday life. Meanwhile, intercultural-oriented language teaching seeks the transformation of students' identities in the act of learning (Singh, binti Marsani, Jaganathan, Abdulah \& Karupian, 2016).

Intercultural competence in foreign language teaching encourages students to be intercultural speakers. Intercultural speakers should be able to act as mediators to embrace the complexities of their cultural identity and that of their counterpart, as well as to avoid the stereotypes accompanying a person (Garrett-Rucks, 2016). To be intercultural speakers, foreign language learners need to acquire intercultural competence. The main components of intercultural competence can be subdivided into five savoir in the conceptual framework compiled by Byram (1997).

The first component of intercultural competence is 'knowledge' (Savoirs). This competence includes the knowledge of their social and cultural groups, similar knowledge about their counseling countries, and similar knowledge of the processes and interactions at the individual/social level.

The second and third components of competence are part of 'skills' which can be divided into Savoir-comprendre and Savoir-apprendre/savoir-faire. For savoir-apprendre/savoir-faire, the skills refer to the ability to learn the culture and determine the meaning of specific cultural phenomena independently. Savoir-comprendre refers to the ability to interpret and relate cultures (Byram, 2015).). 
The fourth and fifth components of competence are part of the 'attitudes', consists of Savoir-etre and Savoir-s'engager. Savoir-etre is the ability and desire to ignore ethnocentric attitudes and views so that learners can establish and maintain relationships between themselves and foreign cultures. Savoir-s'engager refers to a critical engagement with foreign culture under the consideration and personal thought of the learner.

Furthermore, Covert (2014) adds that student's intercultural sensitivity plays an important role to perceive intercultural success. A student with high intercultural sensitivity could be more tolerant of cultural differences. Thus, the student would be able to engage in a more competent communication interculturally.

\subsection{The Role of Textbook in Foreign Language Teaching}

The textbook is one of the most used materials in foreign language teaching. The textbooks are produced by commercial publishers, ministry of education, and institutions. They usually come with supporting materials, such as teacher's book, student's workbook, reading book, visual material (graphic or flash cards), and video or audio material (McGrath, 2013).

From the textbook, students could learn about the culture of target language and teacher could explore the cultural themes. To examine the cultural content, most of the studies have taken a critical orientation and looked at cultural representations as evident in the textual and visual material of textbooks, either as presenting the target language culture, the source culture of the learners, or offering an international cultural orientation which builds on a multitude of contexts and resources (Pasquarelie, 2018). An instrument to study the cultural content in the textbook has been developed by Lee (2009), namely the list of intercultural learning themes.

Table 1. List of Intercultural Learning Themes

\begin{tabular}{|c|c|c|}
\hline \multirow[b]{2}{*}{ General Cultural Themes } & \multicolumn{2}{|c|}{ Specific Cultural Learning Themes } \\
\hline & 'Culture' Learning & 'culture' Learning \\
\hline $\begin{array}{l}\text { 1. The self as a cultural } \\
\text { being } \\
\text { 2. Impact of culture on } \\
\text { human community } \\
\text { 3. Cultural adjustment } \\
\text { stages } \\
\text { 4. Cultural learning } \\
\text { 5. Culture shock: social } \\
\text { distance } \\
\text { 6. Culture stress } \\
\text { 7. Intercultural } \\
\text { development } \\
\text { 8. Cultural identity } \\
\text { 9. Cultural marginality } \\
\text { 10. Cultural learning } \\
\text { strategies } \\
\text { 11. Strategies dealing with } \\
\text { intercultural stress }\end{array}$ & $\begin{array}{l}\text { 1. Races/geography/historical } \\
\text { sites } \\
\text { 2. Arts/crafts/national } \\
\text { treasures } \\
\text { 3. Agriculture } \\
\text { 4. Literature } \\
\text { 5. Medicine/science } \\
\text { 6. Currency/shopping/market/ } \\
\text { Industry/business } \\
\text { 7. Infrastructure/metropolitan } \\
\text { 8. Education } \\
\text { 9. Dress/style/food/housing } \\
\text { 10. Festivals/party/ceremonies/ } \\
\text { celebrations } \\
\text { 11. Holidays } \\
\text { 12. Postal system/mass } \\
\text { communication } \\
\text { 13. Various social customs } \\
\text { 14. Region/regional varieties } \\
\text { 15. Regions }\end{array}$ & $\begin{array}{l}\text { 1. Freedom } \\
\text { 2. Privacy/individualism } \\
\text { 3. Equality/egalitarianism } \\
\text { 4. Fairness } \\
\text { 5. Competition } \\
\text { 6. Materialism } \\
\text { 7. Hard work } \\
\text { 8. Confrontation } \\
\text { 9. Novelty-oriented } \\
\text { 10. Self-improvement } \\
\text { 11. Nurture } \\
\text { 12. Personal control over } \\
\text { environment } \\
\text { 13. Control over time } \\
\text { 14. Action (work)-oriented } \\
\text { 15. Informality } \\
\text { 16. Directness/openness/hone } \\
\text { sty } \\
\text { 17. High involvement } \\
\text { 18. Liberal }\end{array}$ \\
\hline
\end{tabular}




\begin{tabular}{|c|c|c|}
\hline $\begin{array}{l}\text { 12. Intercultural } \\
\text { communicative } \\
\text { competence } \\
\text { 13. Intercultural perspective } \\
\text { taking skill } \\
\text { 14. Ability to culturally adapt } \\
\text { 15. Positive attitude toward } \\
\text { culture learning } \\
\text { 16. Intercultural attitude } \\
\text { toward cultural } \\
\text { differences }\end{array}$ & $\begin{array}{l}\text { 16. Sports/leisure/music/recrea } \\
\text { tion } \\
\text { 17. Traffic/transportation } \\
\text { 18. Family } \\
\text { 19. Meaning of } \\
\text { touch/space/artifact } \\
\text { 20. Nonverbal behaviors } \\
\text { 21. Space communication } \\
\text { 22. Government/politics }\end{array}$ & $\begin{array}{l}\text { 19. Experimental } \\
\text { 20. Future-oriented } \\
\text { 21. Rules/regulations-oriented } \\
\text { 22. Male-dominated } \\
\text { 23. Self-interest oriented } \\
\text { 24. Self-reliance } \\
\text { 25. Weak-face consciousness } \\
\text { 26. Result-oriented }\end{array}$ \\
\hline
\end{tabular}

Based on table 1, it can be concluded that Lee compiled the list of themes covering 16 general culture themes, 22 'Culture' themes, and 26 'culture' themes. The general cultural themes refer to material aimed at enhancing the students' understanding as a cultured human who wishes to learn about other cultures and become intercultural speakers. Cultural aspects are specifically divided into two, namely 'Culture' written in capital letters and 'culture' written in lowercase. The material on 'Culture' refers to issues related to the tangible culture, such as art, history, geography, and others. Meanwhile, 'culture' is related to things that are more abstract and need a deeper understanding, such as values, norms, beliefs, etc.

According to Weninger and Kiss (2013), the textbook provides potential sources of cultural learning. The activity in the textbook should be the unit of examination when studying the cultural potential of language teaching material. In other words, texts, images, and tasks that form an activity should be treated together because it facilitates learning and creates opportunities for cultural messages to surface in the lesson.

\subsection{Developing Intercultural Competence Through Extracurricular Activity}

Aside from learning intercultural competence through the textbook, students could join extracurricular activities to experience the target culture by themselves. Some extracurricular activities that support intercultural competence learning e. g. student exchange, field trip, dance class, cooking class, etc. According to Reva (2012), students who joined in an extracurricular activity are benefited in learning language and intercultural competence. In learning language, students admitted getting significant progress in acquiring vocabularies and improving pronunciation. In learning intercultural competence, they gained more knowledge about the target culture. Moreover, students feel more motivated to learn a foreign language.

Similar research also was done by Liu (2016) who examined the advantages of extracurricular activities for EFL students. First, the students who joined in extracurricular activity gain more friends from different backgrounds. Second, students could practice using English in real-life communication. Third, they gained more appreciations to their origin cultures. Fourth, they obtained positive perceptions of intercultural communication. Fifth, they gained more intercultural awareness.

\subsection{Assessing Intercultural Competence}

The assessment takes an important role in foreign language teaching. With the help of assessment, students know whether they make adequate progress and in which areas 
improvement is needed. For teachers, assessment help them to find out whether their learners are learned what they have taught (Tsagari \& Vogt, 2017).

To assess students' intercultural competence, Skopinskaja (2009) developed a specification of components of intercultural competence by the level of student competence. First, the objective of assessing intercultural knowledge in foreign language learning was to evaluate the learners' understanding of the similarities and differences between the culture from which they originated and the target culture. Second, the objective of assessing intercultural skills was related to the ability of the learners to function and interact in the target language. Third, intercultural attitude assessment aimed at measuring cultural awareness, enabling students to demonstrate openness, and showing students' empathetic attitudes toward other cultures.

\section{Research Method}

This study was conducted by using qualitative research method. There are three research questions in this study. The first research question is on the teaching materials used in learning BIPA at the beginner level in Institution X, the 1A and 1B textbooks. Second, is on the teaching activities of the Indonesian language in the classroom and the cultural programs (cultural class and field trip). Third, is on the $1 \mathrm{~A} \& 1 \mathrm{~B}$ exercise books and tests for beginner level BIPA students. Besides, BIPA teachers and the research and development division manager became informants in the interviews conducted by the researchers to find out how intercultural competence was assessed.

The data were collected by the researchers using four instruments, namely the list of intercultural competence learning themes (Lee, 2009), the researchers' note, audio recording, and interview questionnaire. The list of the intercultural aspect themes was used to analyze the textbooks used for the beginner level of BIPA at Institution $X$ in Yogyakarta. The researchers' records and audio recordings were used at the time of observing the learning process in class and during the cultural programs. Besides, audio recordings and a list of questions were used by the researchers during the interview with the research and development division manager and the teachers. Furthermore, the data that have been collected were analyzed by the researchers to answer the research questions.

\section{Results and Discussion}

\subsection{Textbook Analysis}

The textbooks of Indonesian as a Foreign Language (BIPA) analyzed in this research were compiled by Institute $X$ for the beginner level, namely the $1 \mathrm{~A}$ and $1 \mathrm{~B}$ textbooks. To analyze the content of the textbooks related to intercultural learning, the researchers utilized a list of learning themes from Lee (2009). With the list of themes, the researchers selected dialogues $(D)$, pictures $(P)$, activities $(A)$, and texts $(T)$ related to the intercultural learning themes.

First, the researchers present the findings of the 'general culture' themes in textbook $1 \mathrm{~A}$ in the following table.

Table 2. The General Culture Themes in Textbook $1 \mathrm{~A}$

\begin{tabular}{|l|c|c|c|c|}
\hline \multicolumn{1}{|c|}{ General Culture Themes } & D & P & A & T \\
\hline 1. The self as a cultural being & & & 1 & \\
\hline 2. Intercultural communicative competence & & & 1 & 1 \\
\hline 3. Ability to culturally adapt & & & & 1 \\
\hline Total & $\mathbf{0}$ & $\mathbf{0}$ & $\mathbf{2}$ & $\mathbf{2}$ \\
\hline
\end{tabular}


Based on table 2, it is learned that in textbook 1A there are three themes 'general culture', namely the self as a cultural being, intercultural communicative competence and ability to culturally adapt. The themes were found in activities and texts. The activities were in the form of writing stories about the student's cultural origin and role play. The texts found were in the form of cultural notes and narration.

Furthermore, the theme of 'general culture' was also found in textbook 1B. However, in textbook $1 B$, the researchers only found one theme of 'general culture', namely 'cultural identity'. The theme was found in an activity, namely composing a brief essay on the student's home country. Then, for the discussion of 'specific culture' themes, the researchers divided it according to the categories of 'Culture' and 'culture' learning themes. As mentioned earlier, 'Culture' deals with things that can be seen in its being, whereas 'culture' is abstract. The following is a table listing the 'Culture' learning themes in textbook $1 \mathrm{~A}$.

Table 3. Themes of 'Cultural' Learning in Textbook $1 \mathrm{~A}$

\begin{tabular}{|ll|c|c|c|c|}
\hline \multicolumn{2}{|c|}{ General Culture Themes } & D & P & A & T \\
\hline 1. Races/geography/historical sites & & & 1 & 2 \\
\hline 2. Arts/crafts/national treasures & & 2 & & \\
\hline 3. Currency/shopping/market/industry/business & 3 & & 2 & \\
\hline 4. Infrastructure/metropolitan & & 1 & & \\
\hline 5. Dress/style/food/housing & 1 & 3 & & \\
\hline 6. Festivals/party/ceremonies/celebrations & 1 & 1 & & \\
\hline 7. Postal system/mass communication & 2 & 1 & 2 & \\
\hline 8. Various social customs & & & & 1 \\
\hline 9. Region/regional varieties & & & & 1 \\
\hline 10. Traffic/transportation & 1 & 4 & 2 & 1 \\
\hline 11. Family Total & & & 1 & \\
\hline & $\mathbf{8}$ & $\mathbf{1 2}$ & $\mathbf{8}$ & $\mathbf{5}$ \\
\hline
\end{tabular}

From table 3, it can be learned that in textbook $1 \mathrm{~A}$ there are 11 themes of learning 'Culture'. The themes were found in 8 dialogues, 12 pictures, 8 activities, and 5 texts. The related activities are in the form of interviews, role plays, filling parts of the board, and others. The text containing the knowledge of 'Culture' include cultural notes and narrations.

The theme of 'Culture' learning is also contained in textbook 1B. The following table shows the list of the themes of 'Culture' learning in textbook $1 B$.

Table 4. Themes of 'Cultural' Learning in Textbook 1B

\begin{tabular}{|cl|c|c|c|c|}
\hline \multicolumn{2}{|c|}{ General Culture Themes } & D & P & A & T \\
\hline 1. & Races/geography/historical sites & 1 & 4 & 4 & 3 \\
\hline 2. $\quad$ Arts/crafts/national treasures & & 1 & & \\
\hline 3. $\quad$ Infrastructure/metropolitan & & & 1 & \\
\hline 4. $\quad$ Dress/style/food/housing & & 3 & 1 & \\
\hline 5. $\quad$ Holiday & 1 & & 1 & \\
\hline 6. $\quad$ Sports/leisure/music/recreation & 2 & & 1 & \\
\hline & $\mathbf{4}$ & $\mathbf{8}$ & $\mathbf{8}$ & $\mathbf{3}$ \\
\hline
\end{tabular}

Table 4 shows that the themes of learning 'Culture' in textbook 1B were less than those in textbook 1A. In textbook 1B, the researchers found 6 themes of 'Culture' consisting of 4 dialogues, 8 pictures, 8 activities, and 3 texts. The activities were in the form of responding to 
statements with 'true/false', discussion, presentation, and others. For texts, in addition to cultural notes, the researchers learned that the exposition texts were used to discuss the theme of learning 'Culture'.

Then, the last theme category discussed was the theme of learning 'culture'. The following table shows the theme of 'cultural' learning in textbook $1 \mathrm{~A}$.

Table 5. Themes of 'cultural' Learning in Textbook $1 \mathrm{~A}$

\begin{tabular}{|l|c|c|c|c|}
\hline General Culture Themes & D & P & A & T \\
\hline 1. Hard work & 1 & & & \\
\hline 2. Confrontation & 1 & & 3 & \\
\hline 3. Informality Total & & & & 1 \\
\hline \multicolumn{2}{|c|}{} & $\mathbf{0}$ & $\mathbf{3}$ & $\mathbf{1}$ \\
\hline
\end{tabular}

Table 5 shows that there were three themes of 'cultural' learning in textbook $1 \mathrm{~A}$. The themes were included in 2 dialogues, 3 activities, and 1 text. The activities were role-plays and filling in blanks. The text was a cultural note. The themes of 'cultural' learning contained in textbook $1 \mathrm{~B}$ are presented in the following table.

Table 6. Themes of 'cultural' Learning in Textbook 1B

\begin{tabular}{|l|c|c|c|c|}
\hline General Culture Themes & D & $\mathbf{P}$ & $\mathbf{A}$ & $\mathbf{T}$ \\
\hline 1. Materialism & & & 2 & 1 \\
\hline 2. High involvement & & & 1 & \\
\hline 3. Rules/regulations-oriented & 1 & & 1 & 1 \\
\hline Total & $\mathbf{1}$ & $\mathbf{0}$ & $\mathbf{4}$ & $\mathbf{2}$ \\
\hline
\end{tabular}

Table 6 shows three themes of 'cultural' learning in textbook 1B. The themes were found in 1 dialogue, 4 activities, and 2 texts. The activities were interviews, discussions, and opinions. The texts were a cultural note and an exposition text.

From the aforementioned explanation of the themes of intercultural learning, it can be concluded that the most common categories of themes in the textbooks Bahasa Indonesia $1 \mathrm{~A}$ and Bahasa Indonesia 1B are the categories of the 'Cultural Learning'. Nevertheless, the amount of theme content of 'Cultural learning' and 'General Culture' has been adequately addressed. The results showed that the intercultural learning themes featured in the beginner level textbook are selected to be useful for the survival needs of the learners.

\subsection{Teaching Observation}

In this study, the researchers did not only conduct an observation of the teaching process in the classroom but also in the implementation of cultural programs, namely field trips and cultural classes. For the teaching process in the classroom, the researchers conducted the observation six times. Then, the researchers also observed two field trips. Meanwhile, for the cultural class, the researchers only conducted one observation in the cooking class.

In Institution $\mathrm{X}$, the BIPA learning classes were conducted in a private session or there were only a teacher and student in each class. The researchers observed three classes of $1 \mathrm{~A}$ level and three classes of $1 \mathrm{~B}$ level. This was intended to see how the intercultural competence learning materials in the book were presented and how the teachers explored the themes of intercultural competence in the classroom.

The teaching of the 'knowledge' (Savoirs) about the Indonesian culture can be sourced from the materials in textbooks and information submitted by teachers. Based on the 
observations, the researchers learned that materials of both 'Culture' and 'culture' were discussed during classroom teaching. Usually, the discussions on specific cultural themes occurred by the textbook materials being studied. However, for the study of the cultural influences on language, it occurred after an active learner asked a question to the teacher. Then the 'skills' aspect can be divided into two, namely savoir comprendre and savoirapprendre/savoir-faire. Savoir comprendre refers to the ability to interpret and relate cultures. Meanwhile, savoir-apprendre refers to the ability to learn culture and determine the meaning of certain the cultural phenomena.

The teaching process of the 'skills' of savoir comprendre often occurred in discussions between the teacher and the student in the classroom. Usually, the lesson begins with a question from the teacher: "How about (the culture) in your country?" After that, the students explain the differences or similarities of their culture of origin with the Indonesian culture.

Meanwhile, based on the results of the class observations, there are two patterns of teaching the savoir-apprendre 'skills'. The first pattern is by training the students' skills in interacting through role-play activities. Through role-play activities, the students can practice their skills to interact in a situation resembling the real situations. The teaching pattern of the savoir-apprendre skills is by looking at the skills of how the students have been exploring the Indonesian culture through the stories of the students' experiences. From the second pattern, teachers usually continue by encouraging the students to continue to explore Indonesian culture.

Then, the attitude competence can be divided into two, namely savoir-etre and savoirs'engager. For the savoir-etre attitude, it can be seen from the positive attitude shown by the students during the learning of the intercultural aspects and the students' comments consisting of compliments towards the Indonesian culture. Meanwhile, for the savoir s'engager, the researchers discovered it in the role-play activities aimed at training the attitude of the students in interacting with Indonesians.

Besides, positive results were also found from the observation of the cooking class. In the class, each of the students was asked to practice cooking a recipe written in Bahasa Indonesia printed on paper. The recipe that must be practised by the students in the cooking class included cah kangkong (sautéed water spinach), bakwan sayur (fried vegetable cake), and chicken satay. The teachers were tasked to accompany them during the cooking class. So, when there were things that the students did not understood, such as the name of cooking ingredients or cooking steps, the students could directly ask the teacher. The researchers also observed that teachers tried to convey all instructions and explain things that were not understand by the students by using Bahasa Indonesia.

In contrast to the results of the observation of the teaching process in the class and the cooking class that were quite satisfactory. The researchers discovered unexpected results from the field trip observation. After doing two field trip observations, namely to Borobudur Temple and the Palace of the Sultan of Yogyakarta, the researchers learned that the activity did not support the learning Indonesian language. During the activity, the students only received input of knowledge and information in English. So, it can be concluded that the field trips for BIPA beginner level students were not integrated with the learning of Bahasa Indonesia.

\subsection{Assessment Analysis}

To learn how the teacher assesses the intercultural competence of the beginner BIPA students, the researchers interviewed a lecturer of Institution $X$. The lecturer interviewed was 
a lecturer with the initial ' $E$ ', whose class has been observed by the researchers. In addition, $E$ is also a companion lecturer on the field trip activities to the Palace of the Sultan of Yogyakarta observed for this research.

Before asking about the assessment, the researchers asked the teacher's comprehension of the term 'intercultural'. With some hesitation, the teacher replied that he had heard of the term. Because of that, the researchers also explained the term 'intercultural' in advance in brief, before asking further questions.

Furthermore, the researchers asked about the assessment used to assess intercultural competence. From the interview, it is learned that the related assessment of the intercultural learning is not mandatory for the students due to the limited time and the students' reluctance to leave the class.

In addition to conducting interviews, the researchers also analyzed the assessments for beginner-level students, the $1 \mathrm{~A} \& 1 \mathrm{~B}$ exercise books, as well as the final test. Based on the analysis results, it was understood that the exercise books used as companions to the textbooks were only used to assess the language skills of students only, especially in terms of grammar. The researchers did not see any attempt to assess the students' understanding of intercultural competence learning, although the themes of intercultural competence were studied in the classroom.

The researchers also did not see the test problems intended to assess the learning outcomes of the intercultural aspects in the final test. Although there was a text containing little information about Indonesian culture, the researchers did not find any problems related to it. In fact, if prepared well, questions based on culturally charged texts could have been used to assess the intercultural knowledge of the students.

Those findings are unfortunate because intercultural competence teaching has been done well enough in the observed classes. However, the tests which given to the students did not pay attention to intercultural competence. Therefore, it is important for the responsible parties in Institution $X$ to pay attention to the intercultural aspects in the final test of BIPA beginner level students in order to know about the learning outcomes.

\section{Conclusion}

This study is a case study conducted to determine the extent to which the intercultural competence was considered in teaching Indonesian as a Foreign Language (BIPA) at the beginner level in a course institution. Therefore, the researchers tried to look at the intercultural competence contents of the textbooks used, classroom teaching, and cultural programs, as well as the assessments used at the beginner level.

Based on the results of the textbooks analysis, it is learned that both textbooks Bahasa Indonesia $1 A$ and Bahasa Indonesia $1 B$ contain aspects of intercultural competence learning. The themes of 'Cultural' learning are mostly found in both textbooks. The exposure of 'Cultural' learning in the beginner BIPA textbook is the right step to introduce the Indonesian culture which form can be experienced in everyday life. In addition, the results of the textbook analysis also showed that the team of book compilers also paid attention to the theme of learning 'culture' and 'general culture'. According to the researchers, the content of both categories of themes is sufficient for the survival needs of beginner level students.

Furthermore, based on the observations from six classes of BIPA and one cooking class, the researchers can conclude that the teaching of intercultural competence is conducted well enough. The teaching of the intercultural competence is strongly influenced by the initiative and the enthusiasm of the students because of the limited materials regarding intercultural 
competence learning in the textbooks. The researchers found all aspects of the intercultural competence teaching in the classroom observation.

In contrast to the observations of BIPA teaching classes and cooking classes, the researchers found no satisfactory results from the field trip activities. The researchers also observed that the material in the two field trip activities was delivered in English. The field trips held for beginner level students have not been integrated with the teaching of Indonesian language.

Then, the researchers conducted interviews with the teachers, analysed the exercise books and tests used to learn how the intercultural competence of the beginner level students were assessed. Based on the findings, the researchers learned that Institution $X$ supports intercultural competence teaching at the beginner level. However, Institution $X$ has not considered the importance of assessment to measure the intercultural competence of the students. This is evident from the forms of assessment that focused on assessing language skills only.

Finally, the researchers gave some suggestions and recommendations for the institute where this research was conducted. First, the researchers suggested that the contents of the textbooks used for learning need to be revised or updated. Second, based on the observation and the interviews, it was learned that not all activities related to intercultural competence learning in the textbook were given to the students. Preferably, the activities supporting intercultural competence learning of the students, such as interviews, perhaps not to be ignored. Third, the researchers recommended that there should be a form of assessment of the field trip activities. Prior to following the field trip, teachers could assign tasks to search for information related to the places to be visited. Besides, the institute needs to re-evaluate the final test given for the beginner level students. From the findings, the researchers learned that the tests given did not consider intercultural competence.

\section{References}

Byram, M. (1997). Teaching and assessing intercultural communicative competence. Multilingual Matters.

Byram, M. (2015). Culture in foreign language learning - The implications for teachers and teacher training. In W. M. Chan, S. K. Bhatt, M. Nagami and I. Walker, Culture and foreign lanauge education: Insights from research and implications for the practice (pp. 45-71). Boston: Walter de Gruyter, Inc.

Covert, H. H. (2014). Stories of personal agency: undergraduate students' perceptions of developing intercultural competence during a semester abroad in chile. Journal of Studies in International Education, 18(2), 162-179.

Council of Europe. (2001). Common European framework of reference for languages: Learning, teaching, assessment. Cambridge: Cambridge University Press.

Garrett-Rucks, P. (2016). Intercultural competence in instructed language learning: Bridging theory and practice. Charlotte: Information Age Publishing, Inc.

Lee, K. Y. (2009). Treating culture: what 11 high school EFL conversation textbooks in South Korea do. English Teaching, 8(1), 76-96.

Liu, K. L. (2016). Exploring intercultural competence through an intercultural extracurricular activity in Taiwan. Journal of Language and Cultural Education, 4(1), 99-109.

McGrath, L. (2013). Teaching materials and the roles of EFL/ESL teachers: practice and theory. London: Bloomsbury Academic. 
Moeller, A. K. \& Nugent, K. (2014). Building intercultural competence in the language classroom. Faculty Publications: Department of Teaching, Learning, and Teaching Education, 161.

Pasquarelie, S. L. (2018). Defining an academically sound, culturally relevant study abroad curriculum. In S. L. Pasquarelie, R. A. Cole, and M. J. Tyson (eds.), Passport to change (pp. 28-54). Virginia: Stylus Publishing LLC.

Reva, A. (2012). The role of extracurricular activities in foreign language learning in university settings (Doctoral dissertation, University of Saskatchewan).

Scarino, A. (2010). Assessing intercultural capability in learning languages: A renewed understanding of language, culture, learning, and the nature of assessment. The Modern Language Journal, 94(2), 324-329.

Singh, M. K. M., binti Marsani, et. al. (2016). Promoting intercultural understanding among school students through an English language-based reading programme. Advances in Language and Literary Studies, 7(5), 128-136.

Skopinskaja, L. (2009). Assessing intercultural communicative competence: test construction issues. Synergies Pays Riverains de la Baltique, 6, 135-144.

Tsagari, D. and Vogt, K. (2017). Assessment literacy of foreign language teachers around Europe: Research, challenges and future prospects. Language Testing and Assessment, 6(1), 41-63.

Weninger, C. and Kiss, T. (2013). Culture in English as a foreign language (EFL) textbook: a semiotic approach. TESOL Quarterly, 47(4), 694-716. 